\title{
Yaşam Tarzlarının Farklılığından Bir Dayanışma Tesis Edilebilir Mi? Baumancı Sosyal Teorinin Olanakları
}

\author{
Mustafa Solmaz ${ }^{\mathrm{a}, \mathrm{b}}$
}

Özet

Geleneksel, modern ve postmodern dönemde yaşamın hangi ilkelerden hareketle dizayn edildiğini, yaşam tarzlarının hangi değerlere bağlı olarak temellendirildiğini göstermek araştırmanın amacını oluşturmaktadır. Bunu tespit etmek için kullandığımız yöntem, doküman incelenmesi özelde de içerik analizi olmuştur. Geleneksel dönemde yaşam tarzlarının temellendiricisinin dini söylem, modern dönemde tekil bir hakikat, postmodern dönemde ise hakikatlerin çoğulluğu olduğu tespit edilmiştir. Tekil bir hakikat anlayışından çoğulcu hakikatlere geçişin farklı yaşam tarzlarının gelişmesi açısından bir firsat sunduğu fakat diğer yandan dikkat edilmemesi durumunda bir rölativizm tehlikesi doğurduğu anlaşılmıştır. Rölativizmin neden olduğu zayıflatıcı etkilere karşı herkesin anlaşabileceği temel ilkelerin tespit edilmesi gerektiği sonucuna ulaşılmıştır.

Anahtar Kelimeler

\begin{tabular}{r} 
Anahtar Kelimeler \\
\hline Yaşam Tarzı \\
Geleneksel \\
Modern \\
Postmodern \\
Makale Hakkında \\
\hline Geliş Tarihi: 18.11.2019 \\
Kabul Tarihi: 12.10 .2020
\end{tabular}

Doi: $10.18026 /$ cbayarsos.648362

\section{From the Diversity of Lifestyles Can A Solidarity be Established ? Possibilities of Baumanian Social Theory}

\begin{abstract}
The aim of this research is to show that life is designed in the traditional, modern and postmodern period from what principles and the lifestyles are based on what values. The method we use to determine this has been document analysis and content analysis in particular. It has been determined that the basis of lifestyles in the traditional period is religious discourse, a single truth in the modern period and the plurality of truths in the postmodern period. It has been understood that the transition from a single understanding of truth to the pluralistic truths provides an opportunity for the development of different lifestyles, but on the other hand causes a danger of relativism if not observed. It is concluded that the basic principles that can be understood by everyone should be determined against the weakening effects caused by relativism.
\end{abstract}

Keywords

Lifestyle

Traditional

Modern

Postmodern

\begin{tabular}{r} 
About Article \\
\hline Received: 18.01 .2019 \\
Accepted: 12.10 .2020
\end{tabular}

Doi: $10.18026 /$ cbayarsos.648362

\footnotetext{
a mustafa.solmaz@inonu.edu.tr

b Dr. Öğretim Üyesi, İnönü Üniversitesi, Fen-Edebiyat Fak. Sosyoloji Bölümü, ORCID ID: https: // orcid.org/0000-0002-3323-7448,
} 


\section{Giriş}

Her geçen gün yaşam tarzlarının farklılığının savunulmasına ve bir yaşam tarzının diğerini belirlemesine, onun üzerinde hakimiyet kurmasına karşı çıkıldığına rastlamaktayız. Böylesi bir anlayışın geniş halk kesimlerinde ortaya çıkması ve büyük bir istekle savunulması bir yandan özgürlük bilincinin yerleşmeye başladığını diğer yandan da artan bireyselleşmeyi göstermektedir.

Yaşam tarzlarının farklılığı hiç kuşkusuz tarihin daha önceki dönemlerinde de savunulmaktaydı ancak kimi farklarla. Birinci olarak geçmişte yaşam tarzlarının farklılığ geniş halk kesimlerince değil, oldukça az sayıda insan tarafından savunulmaktaydı. İkinci olarak olağan yani sıradan yaşam tarzından farklı olana saygı gösterilmiyordu ve bunu talep eden kimseler marjinal, suçlu, ahlaksız vb. görülüyordu; günümüzde ise yaşam tarzının farklılığ önceki dönemlere nazaran daha çok hoşgörüyle karşılanmaktadır.

Bir yaşam tarzının diğeri ya da diğerleri üzerinde hakimiyet kurmasının geride kalmasının nedeni bütün yaşam tarzlarının eşit düzeyde haklı ve gerekçelendirilebilir olarak görülmesinden kaynaklanır. Bu değişimin altında yatan şey çoğulcu anlayışların egemen hale gelmesidir. Çoğulcu söylemler postmodern dönemde serpilip gelişme imkânına sahip olmuştur ve bu değişimin temelinde tekil bir hakikat iddiasının geçerliliğini yitirmesi yatar, artık tek bir hakikatten değil hakikatlerden söz ediyoruz. Tek bir hakikat ile ona dayalı olan bir yaşam tarzı egemen bir güç olup diğerleri üzerinde hakimiyet kuramamaktadır. Ortada hakikatler vardır ve onlara bağlı, onlarla ilişkili yaşam tarzlarının hepsi de aynı değerdedir.

Yapmiş olduğumuz araştırma tarihsel süreç içerisinde bu tekil hakikatlerin neler olduğunu, onlardan çoğulcu hakikatlere ve yaşam tarzlarına geçişin nasıl meydana geldiğini göstermeyi amaçlamaktadır. Bunun için Zygmunt Bauman'ın sosyal teorisini merkeze alacağız. Bauman yaşam tarzlarının farklılığını bir yandan olumlar ve önemli olarak görürken diğer yandan bu durumun bizleri birbirimize kayıtsız hale getirmesine engel olmak için yeni bir dayanışma tesis etmeye çalışır. Tesis edilecek olan dayanışmayı da ötekinin farklılığı üzerine dayandırmaya çalışır. Biz de bunun mümkün olup-olmayacağını araştıracağız.

\section{Geleneksel Dönem}

Geleneksel yaşam dini düşüncenin etkisi altındaydı ve özgürlük Tanrı'nın emirlerine karşı gelmekti ya da Tanrı́nın buyurduğu şekliyle dünyanın yolundan ayrılmaktı. Alışıldık davranma tarzlarından sapan her şey bir ihlal olarak değerlendiriliyordu ve doğru yolda olmak bir seçim meselesi değildi (Bauman, 1998). “Adım gibi emindim ki, ben bir şey istediğimde ya da istemediğimde bunu isteyen ya da istemeyen benden başkası değildi. İşte yavaş yavaş anlamaya çalıştığım günahın sebebi buydu." (Augustinus, 2010)

Augustinus önemli bir açmazla karşı karşıya kalır: Bir tarafta dünyada kötülüğün inkâr edilemeyecek gerçekliği diğer tarafta ise her şeyi yaratan bir Tanrı'nın varlığı. Günah ve kötülük varsa bu dünya Tanrı'nın eseri olamaz. Bu mümkün değildir çünkü Tanrı her şeyin yaratıcısıdır ve $\mathrm{O}$, özü itibariyle iyi bir varlıktır. Fakat dünyada sürekli işlenen günahlara ve kötülüklere rastlıyoruz. Bu açmazdan nasıl kurtulabiliriz? Yanıt, her şeyi yaratan bir Tanrı'nın varlığını ve aynı zamanda dünyada günahın, kötülüğün vb. işlendiğini kabul etmekten geçer. Bu bakış açısı bir çelişki oluşturmaz şöyle ki Tanrı bütün her şeyi olduğu gibi insanı da hiçlikten meydana getirmiştir ancak tek bir farkla: İnsanı özgür bir varlık 
olarak yaratmıştır. İnsan ancak sahip olduğu özgürlüğe bağlı olarak Tanrı'nın emirlerine karşı gelebilir ve böylelikle günaha, kötülüğe bulaşabilir. Günahın ya da kötülüğün dünyada gerçekleşmesinin sebebi bu anlamda Tanrı değil, O'nun emirlerine karşı gelen insanın iradesi, istencidir. İstenç vasıtasıyla gerçekleşmemiş ise bir eylem ahlaki anlamda iyi ya da kötü değildir. İnsanlar özgür istence sahip olmasaydılar nihai bir hesap günü ve buna bağlı olarak cezalandırma ya da ödüllendirme de olamazdı (Augustine, 2006).

Geleneksel dönemde insanların yaşamlarının denetlendiğini teyit eden bir diğer şey Foucault'nun bahsettiği pastoral iktidardır. Yunan ve Roma antikçağında, doğumlarından ölümlerine kadar bazı bireylerin diğer bireyleri yaşamları boyunca güderek onlara çobanlık görevi oynayabileceği düşüncesi asla olmamıştır. Yunan ve Roma'da yönetenler papaz veya çoban olarak tanımlanmamışlardır (Foucault, 2011a). Pastoral iktidara Yunan veya Roma dünyasında rastlanılmaz. Onunla Doğu Akdeniz, Mısır, Mezopotamya ve Asur'da karşılaşılır. Sürü ve çoban konusuna politik olmakla birlikte dinsel, ahlaki ve toplumsal bir tema olarak özellikle İbrani toplumunda rastlanır: Tanrı halkının çobanıdır ve halkı da onun sürüsüdür. İsrail oğullarının ilk kralı olan Davud, sürüsü olacağı halkın çobanı olma vasfını Tanrı'nın elinden kabul eder ve onun için sürünün nihai olarak ağıla girdiği ve cennete ulaştığı gün Yahudilerin selameti gerçekleşmiş olacaktır (Foucault, 1990, 2011a).

Çobanın sürüsü üzerindeki egemenliği anlamına gelen pastoral iktidarın amacı sürünün selameti, kurtuluşa ermesidir. Papaz kendisine tabi olan inananların yaşamlarını gözetlemeli, denetlemeli ve gerekirse düzeltmelidir. Pastoral iktidar somut bir toprak ya da benzeri bir şey üzerinde uygulanan egemenlik türü değildir. Onun uygulama alanı bireylerdir daha doğrusu onların ruhlarıdır. Pastoral iktidar, inananların ruhları üzerinde uygulanan iktidardır. Hıristiyan toplumunda bireyler "ben selameti, kurtuluşu" istemiyorum diyemez, böylesi bir özgürlük talebinde bulunamazlar. Her bireyden selameti araması istenilir ve papazın iktidarının kurulması, bu insanların kurtuluşu için gerekli olan şeyleri yapmasını sağlayacak bir otoriteyi oluşturmasına bağlıdır, bu onun birinci özelliğidir. Selametleri için lüzumlu olan her şeyi yapmaya bireyleri zorlayabilmesi, pastoral iktidarın ikinci özelliğidir. Üçüncüsü mutlak bir itaati talep etmesidir. Ne Yunan ne de Roma toplumları mutlak ve koşulsuz bir itaat görmüşlerdir. Böylesi bir duruma Hıristiyanlıkla birlikte geçilmiştir. Çünkü Hıristiyanlıkla birlikte mutlak değer itaatkârlık haline dönüşmüştür ve itaatkâr olmak, diğer bütün erdemlerin koşulu olarak görülmüştür. Pastoral iktidarın dördüncü özelliği hem öğretmesi hem de inananların durumları hakkında bilgi sahip olmasıyla ilişkilidir. Papaz hakikati, kutsal kitabı öğretir. Bu yönüyle antikçağın bilgesi, hakikat hocası gibidir. Ama öte yandan onlardan farklı olarak pastoral yükümlülüğünü yerine getirebilmesi için her üyenin yaptıklarını bilmek zorundadır. Bireylerin ruhlarında, yüreklerinde, en gizli yerlerindeki sırlarına vakıf olmalıdır. Pastoral iktidar bireycidir, bireylerin bütün yaptıklarını bilendir ve bu onun beşinci özelliğidir. Kralın ve memurların görevi devletin bütünlüğünü, bölünmezliğini, şehri ve yurttaşları korumak iken; pastoral iktidarın görevi tekil bireylere göz kulak olmaktır (Foucault, 2011a).

\section{Modern Dönem}

Geleneksel dünyanın sonlarında dini düşüncenin ve denetimin etkisi zayıflamaya başlamış ve birbirinden farklı davranış tarzlarıyla karşılaşılmıştır. XVI. yüzyılda yaşamış olan Montaigne (2007: 96) için insanların davranışlarının göreliliği ne bir sorun ne de çözülmesi gereken bir problemdir. Çünkü henüz ortalıkta mutlak hakikatle ilgilenecek ya da ona alıc1olmaya aday olacak bir iktidar yoktur. Aksine birbirlerinden farklı olan tüm insan davranış 
biçimlerinin eşit derecede iyi olarak karşılandığı ve farklılıklar hakkında yaygara koparmanın gereksiz görüldüğü dönemlerdi. Ancak kısa bir süre içinde bu durum değişecekti (Bauman, 2003a: 109). Merkeziyetçi iktidar yapısının gelişimi ve kesinliğe dayalı epistemoloji arayışları nedeniyle Montaigne dönemindeki farklılıklara yönelik müsamaha ortadan kalkacak ve onun yerine egemen bir yaşam biçimi belirlemeye başlayacaktı.

Uygarlaştırma peşinde olanların hırsları ile Montaigne'in alçak gönüllüğü birbirinden çok farklıydı. Artık yöresel, yerel yaşam tarzlarına karşı sergilenen hoşgörü ortadan kalkmaya başlamıştı. Yeni düzen tarihsel olarak gelişmiş göreneklere bağlı kolektif deneyimlere dayanmayacaktı. Aksine bu gelenekler kırılmalıydı. Yöresel geleneklerden kalan her şey, toplumsal düzenin korumasını eline alacak olan mutlakıyetçi devlet için düzenli topluma giden yoldaki engeller olarak görülmeliydi. Modern devletin tüm yerel iktidarları dar, geri kalmış ve gerici duruma getirmesi gibi ona meşruiyet ve strateji sağlayan uygarlaştırma projesi de yerelliklere dayalı yaşam tarzlarını geri ve batıl itikatlı bir duruma çevirmeliydi (Bauman, 2003a).

Yapılması gereken şey, eğitime aç bir topluma eğitim süreçlerini getirmek değildi; aydın olmayan veya kötü niyetli öğretmenlerin verdikleri eski, zararlı eğitimin yerine akla dayanan, hem bireye hem de topluma faydalı bir eğitimi seçmekti. Rahipler, kocakarılar ve eski atasözleri karanlık güçlerin temsilcileriydiler (Bauman, 2003a). Amaç hem toplumun genel olarak bilgilendirilmesi hem de onların yalan, yanlış bilgilerden uzaklaştırılıp doğru bir eğitim sürecinden geçirilmeleriydi.

Modern dönemin özellikle de aydınlanma sürecinin ereği yalnızca soyut ve genel düzeyde bir bilgilenme, bilgilendirme süreci değildir. Aynı zamanda genel halk kitlelerinin somut olarak eğitilmesidir. Bundan dolayı okul çok önemlidir. Okul adeta bir mikro toplumdur ya da toplum mikro bir okuldur. Genel olarak toplum bir eğitim yuvası haline gelmiştir.

Toplumun büyük ölçekli bir eğitim yeri haline gelmesinin sebebi modern iktidarın siyasal hakikatinden kaynaklanır. Doğru olanın merkezi bir iktidar yapısına sahip olmaktan geçtiğinin farkına varan modern devlet meşruiyetini sağlamak için yaşam dünyalarında, kültürde ve eğitimde de merkezileşmeyi, bütünleşmeyi sağlamaya çalışacaktır. İşte okullar verdikleri eğitim vasıtasıyla tam da bunu gerçekleştireceklerdir. Bireylerin hep birlikte nasıl davranmaları, yaşamaları gerektiğini belirleyeceklerdir.

Daha önceden kuramsal öngörülerini siyasal uygulama düzeyine yükseltecek güçteki kaldıraçlardan yoksun olan Aydınlanma Çağı'nın söylemi tam olgunluğa Devrim döneminde ulaşmıştır. Bu süreçte pratik önlemler imgelem üzerinde birer kısıtlama oluşturmaktan ziyade kuramsal gerekliliklere uygun hale getirilecek şekilde biçimlendirilmeye başlanmıştır (Bauman, 2003a). Lepeletier'nin taslağını çizdiği, Robespierre'in de Kurucu Meclis'e sunduğu en kapsamlı ulusal eğitim projesi, örnek okulu; içinde her şeyin görülebildiği, herkesin gözetim altında tutulduğu ve hiçbir ayrıntının kuralsal düzenin dışına çıkamadığı bir yer olarak tanımlamıştır (Bauman, 2003a). "Sürekli olarak uygulanan etkin bir gözetim altında her saat uyuma, yemek yeme, çalışma, egzersiz ya da dinlenme saati olarak belirlenecektir; tüm yaşam tarzı değişmez bir biçimde düzenlenecektir... Gelişim sağlayıcı ve tekbiçimli bir düzenleme her ayrıntıyı öngörecek ve bunun istikrarlı ve kolay bir biçimde uygulanması iyi etkiler elde edilmesini sağlayacaktır... Eski soyumuzun önyargılarıyla girecekleri yozlaştırıcı her tür teması anlaşılması olanaksız, 
bir duvarla ayrılan yeni, güçlü, çalışkan, düzenli ve disiplinli bir ırk [yaratılacaktır]" (Bauman, 2003a).

Robespierre'in sunduğu ulusal eğitim projesi anlaşılacağı üzere modern toplumun bir gözetim toplumu olduğunu sembolize eden panopticon tarzı mimarinin amaçlarıyla oldukça ilişkilidir. Bentham'ın projesini sosyal teorisinin temeli haline getiren Foucault (2011b, 2013)'nun bahsettiği kapatılma mekânları genel olarak atölyeler, hapishaneler, hastaneler ve bunlarla birlikte bir de okullardır. Gerek Foucault'nun sosyal teorisinin gerekse de ondan önce Robespierre'nin sunmuş olduğu taslağın gösterdiği şey, bütünleşmiş bir toplumun bireylerin yetiştirilme tarzını disipline etmeye ihtiyaç duymasıdır. Daha doğrusu bütünleşmiş bir toplumun yani ulusun bireylerin yaşamlarını nasıl düzenlenmeleri gerektiğini belirlemesidir.

Bireylerin hep birlikte disiplinlere tabi tutulmaları aslında onlar arasındaki ortaklığı, yaşam tarzlarının birlikteliğini kuracak olan şeydir. Standardize bir şekilde eğitilecek bireyler genel bir yaşam tarzının nasıl olduğunu, olması gerektiğini öğrenmiş olacaklardır. Ancak böylelikle ulusal bir toplumun ihtiyaç duyduğu bireyler üretilmiş olacaktır.

Eğitimin bir başka şekilde değil de bu şekilde gerçekleştirilmesinin amacı politik merkezileşmenin meşruiyetini sağlamak iken; elde bulundurulacak ölçüt ise bilim ve akıldır. Ancak bilime ve akla dayanan projeler geçerli olabilir. ${ }^{i}$ Doğruyu yanlıştan ayırt eden, neyin iyi ya da neyin kötü olduğunun yargısını veren ve buradan hareketle nelerin yapılması gerektiğini belirleyen ise entelektüel olacaktır. Entelektüeller modern toplumda yasa koyucu olarak hareket etmişlerdir. Buradaki yasa koyucuyu yalnızca hukuksal normların üretilmesi ve öne sürülmesiyle ilişkilendiremeyiz, daha genel ölçekte değerlendirmeliyiz. Entelektüeller doğruyu ve yanlışı bildikleri için gerçekleştirilmek istenen şey her ne ise o konuda yargıda bulunabilme otoritesine sahiptirler. Neyin yanlış olduğunu ve kaçınılması gerektiğini, neyin doğru olduğunu ve yapılması gerektiğini belirleyen onlar olmuşlardır. Entelektüellerin bu rollerinin altında yatan şey, değişmez bir hakikate sahip olduklarına inanılmasıdır. Peki tek bir hakikat düşüncesinin zarar görmesi durumunda ne olacaktır?

\section{Günümüz}

Modern uygarlaştırma projesi özünde görecelikle yani yaşam tarzlarının çoğulluğuyla bir baş etme çabasıydı. Önem kazanan şey hiçbir karşıtlı̆̆a müsaade etmeyen ve herhangi bir ödün vermeyen tutarlı bir mutlak insan uygarlığı kavrayışıydı (Bauman, 2003a). Ancak çoğulculuğun yaygınlaşması, dünya görüşleri ve değerler konusundaki evrensel mutabakatın çözülmeye başlaması, mevcut tüm Weltanschaungen'ların (dünya görüşlerinin) önem kazanmasıyla birlikte gelenekler arası iletişim, çağımızın en önemli sorunu haline gelmiştir. Kültür geleneklerini birbirlerine tercüme edebilecek uzmanlara ihtiyaç duyulmaya başlanmıştır. Bundan dolayı entelektüelin rolü artık yasakoyucu olmaktan çıkmıştır ve yorumcu rolüne dönüşmüşsür (Bauman, 2003a).

Modern aklın egemenliği sabit tanımlara, tanımlamalara dayandığı için kesin bir şekilde belirlenemeyen her şey bir anormallik ve meydan okuma olarak görülmüştür. Gerek akla gerekse de tek bir hakikat düşüncesine şüpheyle bakılmaya başlandığı postmodern dönemde ise kabul gören şeyler şey tam da modern aklın ötekisi olan çokanlamlılık, çokanlamlı tanımlar, bilişsel uyumsuzluk ve olumsallık olmuştur (Bauman, 2003b). Modern dönemde farklı olan, yabancı olarak görülen kimseler tehdit olarak değerlendirilip dışlanmışlarken; 
postmodern zamanlarda farklılık yalnızca kaçınılmaz bir şey değil fakat aynı zamanda iyi, değerli ve korunması gereken bir şey (Bauman, 2000) olarak görülmüştür.

Farklı olana, bizden olmayana yönelik olumlu yöndeki bakış açısı değişikliğinin temelinde hakikat algısının geçirdiği dönüşüm yatar. Postmodern dönemde artık tek bir hakikat değil eşdeğerde olan hakikatler vardır ve bunlardan birisinin diğeri üzerinde herhangi bir egemenliği yoktur. Bu değişimin neden olduğu sonuç ise çoğulculuk olmuştur. Çoğulculuk postmodern dönemin geçici bir uğrağı değil aksine kurucu bir unsurudur. Bundan dolayı farklı düşüncelere ve yaşam tarzlarına yönelik bir hoşgörü oluşmuştur. Farklılık bir baskı gerekçesi olarak görülmemiş ve farklı yaşam biçimlerinin bir arada bulunma ihtimalleri mümkün hale gelmiştir. Özgürlük, eşittlik ve kardeşlik, modernliğin mottosudur; Özgürlük, farklılık ve hoşgörü ise postmodernliğin ateşkes formülü haline gelmiştir. Hoşgörünün dayanışmaya dönüşmesiyle birlikte ise bu ateşkes barışa dönüşebilir (Bauman, 2003b).

Hoşgörülü olmak, tehlikeden uzak durmak için yeterli görülebilir (Bauman, 2003b). Ötekilerin yaşamımıza zarar vermemeleri için onların da yaşamasına (istemeyerek de olsa) hoşgörü sergileyebiliriz. Bu açıdan hoşgörü her ne kadar farklı yaşam tarzlarına bir olanak sağlıyor gibi görünse de özgürleşme için yeterli değildir. Hoşgörünün dayanışmaya dönüştürülmesi gereklidir (Demirtaş, 2013). Çünkü toplumlarımızda eskisine oranla daha fazla uzamsal hareketlilik ve yer değiştirme söz konusudur. Daha önceden olduğu gibi birbirimize benzer insanlarla bir arada bulunmuyoruz. Bizden farklı olan, farklı düşünen insanlarla karşı karşıya geliyoruz.

Son dönemlerde ulusal hükümetler vasıtasıyla göçmenlik karşıtı yasaların geçirilmeye çalışılması şaşmaz bir şekilde bizlere artık göçmenliğin evrensel bir olgu haline geldiğini gösteriyor. Özellikle de savaş, yoksulluk ya da başka gerekçelerle insanlar yerlerini terk edip, kendi yaşam dünyalarını bırakıp başka ülkelere, toplumlara, kültürel çevrelere yönelmektedirler. Amaçları daha güvenli ve refah bir yaşama ulaşmaktır. Onların amaçladıkları şeylere ulaşıp ulaşmayacağını bilmiyoruz. Fakat emin olduğumuz şey göçmen hareketlerinin her geçen gün artması ve etrafımızı kuşatmasıdır. Bundan dolayı artık sokaklarda, kaldırımlarda, alışverişte veya başka yerlerde bizden olmayan, bizim gibi davranmayan insanlarla karşı karşıya geliyoruz ve onların eylemlerinin üzerimizdeki etkilerini hissediyoruz.

Ötekilerin bizlere bu kadar yanaşmasına karşılık verdiğimiz yanıt ise Bauman'a göre bütün bir toplumu korku ve belirsizlik kaynağına dönüştürmektir. Kapısında bekçiler olan daha güvenli siteler kurmak, her yeri güvenlik kameralarıyla kaplamak, kapı girişlerini daha güvenilir hale getirmek ve daha birçok şey için uğraşıyoruz. Amacımız korku ve belirsizlik kaynağı haline gelmiş olan toplumdan bir an önce kendimizi yalıtmak ve güvenli, korunaklı şatolarımızda yaşamaktır. Fakat kişi, yabancının barındırdığı tehditten endişe duyması nedeniyle onlarla ne kadar az vakit geçirirse, "beklenmeyene duyduğu hoşgörü ve takdir" o derece azalır. Benzer bir biçimde şehir yaşamının canlılığıyla, dinamizmiyle ve çeşitliliğiyle yüzleşme, onunla başa çıkma ve bundan zevk alma yetisi de o derece düşer (Bauman, 2013). Dahası insanlar arasında en çok ihtiyaç duyulan güvenlik hissi ortadan kalkar ve birbirimize karşı duymuş olduğumuz güvensizlikler belirleyici hale gelir.

Önümüzde ya güvenliği merkeze alıp her şeyi bir korku kaynağı olarak görmek ya da korkularımızla yüzleşip, onları aşmaya çalışmak şeklinde iki yol vardır. Bauman ikinci yolu seçer, bunun da özen ve zahmet gerektireceğini belirtir. İyi niyetli ve saygıya dayalı bir 
diyalog ona göre ortak olarak paylaştığımız gezegende hayatta kalmamızın zaruri koşulu haline gelmektedir. Fakat bunun hem elde edilmesi hem de korunması zordur. Bu zorluğun üstesinden ise ancak karşılıklı iyi niyet, bağlılık, taviz, saygı ve insanın aşağılanmasının her türüne karşı ortak bir rahatsızlık sergileyerek gelebiliriz. En önemlisi de güvenlik ile ahlaksal sorumluluk arasındaki bozulmuş dengeyi yeniden düzeltmeye yönelik bir kararlılıkla (Bauman, 2013) bunu gerçekleştirebiliriz. Farklılık taleplerine uygun olarak sürdürülebilir bir aradalığın tesisi için belirtmiş olduğumuz şeyler oldukça önemlidir fakat yetersizdir. Onlardan daha fazlasina ihtiyacımız var.

Artık ötekilerin farklılıklarının bizim farklılıklarımıza dokunmadığı müddetçe rahat edeceğimiz bir dünyada yaşamıyoruz. Başkalarının farklılıkları, bizimkileri kısıtlama ya da engelleme olasılığ olduğu bir dünyada hayatta kalmamamızın tek yolu her bir farklılığın diğer bir farklılığ kendisinin gerekli koşulu olarak görmesinden geçer. Farklı kimliklerin birbirlerini dışlamalarına son verilmelidir. Kendi kimliğimizi kanıtlama adına öteki kimlikleri baskı altına almamalıyız ve tam tersini yapmalıyız. Kendi benzersizliğimizin gelişimini mümkün kılan diğer farklılıkları muhafaza eden öteki kimlikleri savunmalıyız, onlar için mücadele etmeliyiz. Ancak böylesi bir mücadele ötekilerle bir dayanışmaya imkân sağlayabilir. Dayanışma kendi farklılığımız için değil, ötekinin farklılı̆̆ edilebilir (Demirtaş, 2013). Dayanışma, ötekinin farklılığı üzerine inşa edilebilir. Ötekinin farklılığına saygı duymakla kalmayıp bizim ötekilerle birlikte onların farklılığ 1 için mücadele etmemizle gerçekleşebilir.

\section{Tartışma, Sonuç ve Öneriler}

Farklı yaşam tarzlarına yönelik olumlu bir tavrın gerekçelendirilebilirliği açısından postmodern dönemin çoğulcu hakikat anlayışı önemli bir fırsat sağlar. Bir hakikatin diğeri karşısında haklılı̆̆ının azalması daha doğru bir deyişle bir hakikatin diğerinden ya da diğerlerinden daha üstün olmadığının anlaşılması, en temelde geleneksel olan yanlış ile doğru arasındaki farkın azalmasına yol açar. "Düzeltilmesi gereken yanlış" düşüncesini, ortadan kaldırır. Bu açıdan farklı yaşam tarzlarının bir arada olmasına imkân sağlar.

Diğer yandan bizleri bir göreliliğe de mahkum eder, evrensel ve genel bir ortak ilke belirlememize engel olur. Özgürlüklerimiz açısından hakikatlerin eşdeğerliliği önemli olduğu kadar evrensel hakikatlere de gereksinimiz var. Evrensel hakikatlere neden ihtiyacımız var? a) Bütün eylemlerimize ufuk vermeleri açısından onlar bizim için önemlidir. Onlar yolumuzdan sapmamamız için gerekli olan erekleri ifade ederler. b) Evrensel hakikatler ereklerimize varmak için ortaya koyduğumuz düşünce ve davranışların bir araya gelip, daha güçlü bir şekilde değiştirici-dönüştürücü olmaları için önemlidirler.

Hakikatlerin hem göreliliğine hem de evrenselliğine önem göstermeliyiz. Farklı yaşam tarzlarının meşruiyetlerinin temellendirilebilirliği açısından hakikatlerin göreliliğine; onların bir arada yaşamalarının olanaklıkları açısından ise hakikatlerin evrenselliğine ihtiyacımız var. Yaşam tarzlarının farklılı̆̆ının savunulabilirliği önemlidir, onların bir arada bulunabilirliklerinin koşullarının neler olduğu ise daha da önemlidir. Bauman bu konuda iki şey öne sürmektedir. Bunlardan ilki, “... iyi niyet, bağlılık, taviz, saygı ve insanın aşağılanmasının her türüne karşı ortak bir rahatsızlık..." sergilemektir. Yine bununla ilişkili olarak güvenlik ile ahlaksal arasındaki bozulmuş dengeyi yeniden kurmaktır. İkincisi ise “... 
her bir farklılığın diğer bir farklılı̆̆1 kendisinin gerekli koşulu olarak görmesinden geçer." Yalnızca kendi farklılığımızı savunmamalı, diğerinin farklılı̆̆ için de mücadele etmeliyiz.

Kendileriyle birlikte, kendileri için hareket ettiğimiz insanların farklılık taleplerinin bizlerin ya da başkalarının farklılıklarına zarar verme durumları olabilir mi? Şayet yoksa, herhangi bir zorluk da oluşmaz dolayısıyla üzerinde durmaya değmez. Şayet varsa, işte o zaman bunun üstesinden nasıl gelebiliriz? Bu duruma nasıl bir sınır çizip, belirli hale getirebiliriz?

Bahsedilen sorulara yanıt vermek oldukça güçtür. Çünkü her sınır çizme girişimi farklılıktan ve özgürlükten korkmak anlamına da gelebilir. Ama diğer yandan bu sınırı çizememek bizleri bir kör düğüşünün içerisine de atabilir. Bulunduğumuz yerden daha ileri bir noktaya erişebilmek için problem alanımızın sınırlarını iyi çizmeliyiz.

Farklı yaşam tarzlarının meşruiyetlerini savunurken bu sürece zarar vermemek için aşılmaması gereken bu sınır ne olmalıdır? Locke'un ve diğer bazı isimlerin söyledikleri gibi "yaşam hakkı, mülkiyet ve özgürlük" mü olmalıdır? Yaşam hakkı ve özgürlük noktasında herhangi bir problem görünmezken, mülkiyet konusunda acaba liberalizmin daha da ileri gidilerek kapitalizmin savunuculuğunu yaptığımız eleştirisi yöneltilebilir mi? Yoksa Kant’ın kategorik imperatiflerinin başka deyişle koşulsuz bu anlamda da her zaman ve her koşulda gerçekleştirilmesi gereken kesin emirlerin içeriğini dolduran maksimler mi bu sınırı belirlemelidir: Genel yasa olacak şekilde eyle! İnsanı ne kendinde ne de bir başkasında her zaman bir araç olarak değil, amaç olarak gör! Özgürlüğe uygun olarak eyle (yani kendi kurduğun yasaya uygun davran)! Kesin olarak bilmiyoruz. Fakat bu saydığımız şeylerden "mülkiyet" hariç (çünkü onu kabul etmeyenler olabilir); "yaşam hakkının”, "özgürlüğün”, "genel bir yasa olacak şekilde davranmanın" ve "insanı bir amaç olarak görmenin" iyi bir başlangıç oluşturacağını düşünüyoruz. Bizden sonraki araştırmacıların vardığımız bu başlangıç noktasının gerçekleştirilebilirliğini sorgulamalarını ve mümkünse de onun ötesine ulaşmalarını temenni ediyoruz.

\section{Kaynakça}

Augustinus, A. (2006). On free choice of the will. M. Cahn Steven (Der.), Classics of Western Philosophy içinde (s. 357-373). Indianapolis: Hackett Publishing Company.

Augustinus, A. (2010). İtiraflar. Çev. Çiğdem Dürüşken. İstanbul: Kabalcı Yayınevi.

Bauman, Z. (1998). Postmodern etik. Çev. Alev Türker, İstanbul: Ayrıntı Yayınları.

Bauman, Z. (2000). Postmodernlik ve hoşnutsuzlukları. Çev. İsmail Türkmen, İstanbul: Ayrıntı Yayınlar1.

Bauman, Z. (2003a). Yasa koyucular ile yorumcular, Çev. Kemal Atakay, İstanbul: Metis Yayınları.

Bauman, Z. (2003b). Modernlik ve müphemlik. Çev. İsmail Türkmen, İstanbul: Ayrıntı Yayınları.

Bauman, Z. (2013). Modernite, kapitalizm, sosyalizm: küresel çağda sosyal eşitsizlik. Çev. F. Doruk Ergun, İstanbul: Say Yayınları.

Demirtaş, M. (2013). Panoptikon'dan sinoptikon'a: öteki için/kadar özgürlük. Zülküf Kara (Der.), Bauman sosyolojisi içinde (s. 243-263). İstanbul: Ayrıntı Yayınları.

Descartes, R. (1984). Metot üzerine konuşma. Çev. K. Sahir Sel. İstanbul: Sosyal Yayınlar. 
Descartes, R. (1986). Aklın yönetimi için kurallar. Çev. Müntekim Ökmen. İstanbul: Sosyal Yayınlar.

Foucault, M. (1990). Politics, philosophy, culture. Translated by Alan Sheridan and Others. Edited with an introduction by Lawrence D. Kritzman. New York: Routledge, Chapman \& Hall, Inc.

Foucault, M. (2011a). Entelektüelin siyasi işlevi: seçme yazılar 1. Çev. Işık Ergüden-Osman Akınhay-Ferda Keskin. İstanbul: Ayrıntı Yayınları.

Foucault, M. (2011b). Büyük kapatılma: seçme yazılar 3. Çev. Işık Ergüden-Ferda Keskin, İstanbul: Ayrıntı Yayınları.

Foucault, M. (2013). Hapishanenin doğuşu. Çev. Mehmet Ali Kılıçbay, Ankara: İmge Kitabevi.

Kant, I. (1993). Arı usun eleştirisi. Çev. Aziz Yardımlı. İstanbul: İdea Yayınevi.

Kant, I. (2009). Ahlak metafiziğinin temellendirilmesi. Çev. İonna Kuçuradi. Ankara: Türkiye Felsefe Kurumu.

Montaigne (2007). Denemeler. Çev. Sabahattin Eyüboğlu. İstanbul: Türkiye İş Bankası Kültür Yayınları.

\title{
Açıklamalar
}

\begin{abstract}
${ }^{i}$ Modern dönemin filozofları da akla dayalı anlayışları savunmuşlardır. "İncelemelerin amacı akla, karsısına çıkan her şey üzerine sağlam ve doğru yargılara varmayı sağlayacak bir yönetim vermek olmalıdır" (Descartes, 1986). Aklın yasalarını koymak ve yürütmek, bu azınlığın, hakikati bilenlerin, felsefecilerin sırtındaki yüktür. Bu insanlar çoğunluğun mutluluğunun tek çaresi olan bu görevi icra etmeye davet edilirler (Bauman, 2003b): “Uğraşmamız gereken konular, yalnızca, aklımızın kesin ve açık bir bilgi edinmeye yeteceğini kestirdiklerimiz olmalıdır." (Descartes, 1986).
\end{abstract}

Descartes birçok göreneğe ve sayısız yaşam tarzına bölünmüş ve hiçbir yaşam tarzının, kabul edilmesinin koşulu olarak kendi aşinalığı dışında başka bir şeyi gösteremediği bir dünyayı bulmuştur karşısında. Böyle bir dünya onun için sorunlu, ürkütücü ve öfkelendiricidir bundan dolayı hemen harekete geçilmelidir. Yeni kesinlik çağının gündoğumunda Descartes "insanların davranış tarzları"n1, görkemli hakikat söyleminin otoritesinden yoksun "basit" görenekler olarak yerip bir yana bırakacak ilk kişi olacaktır (Bauman, 2003a). Kendisinin geliştirdiği düşünce biçimine göre bir yaşam tarzı kurgulayacaktır. Cogito'ya bağlı olarak kesin bir ahlak geliştirene kadar halihazırdaki geleneklere-göreneklere göre hareket edecektir. Fakat onu tesis ettikten sonra artık başka bir şeye göre değil de, aklın buyurduklarına göre davranacaktır (Descartes, 1984).

Descartesçi, Leibnizci ve Wolfçu geleneğin a priori tarzdaki bilgi görüşlerinin temelde bizlere yeni bilgi vermediğini, yüklemin öznede içerildiği (Bekârlar evli olmayanlardır) biçimde yalnızca bilinen şeyi tasdik ettiğini fark eden Kant, yüklemin öznede içerilmediği ve bu anlamda da yeni bir bilgi içeren a posteriori bilgiyi önemseyen İngiliz ampirizmine yönelir. İngiliz ampirizminin a posteri tarzda yargılara ulaştığını ancak onların verdiği bilgilerin tekil deneyimlere ait olduğunu anlar. Buradan genel ve zorunlu bir bilgiye ulaşılamayacağını anlayan Kant (1993) Descartes, Leibniz, Wolfçu geleneği ve Humecu ampirist anlayışı bir araya getirerek hem zorunlu ve hem de yeni bir bilgi verecek olan sentetik a prori yargıların nasıl kurulacağını göstermek için Salt Aklın Eleştirisi'ni yazar. Amacı hem zorunlu hem de yeni bir bilgi veren yargıları göstermektir. 
Kant ahlakta da benzeri bir şekilde hareket edip mutluluğa dayalı rastlantısal amaçları bir kenara bırakıp değerini eylemlerin sonuçlarında değil de ilkelerinde arayan ödeve dayalı ahlakı savunmuştur. Bu ilkeleri de maksimler şeklinde ifade edip her ne koşulda olursa olsun gerçekleştirilmeleri gerektiğini (kategorik imperatif) ifade etmiştir. İşte bu maksimlerin bazıları "Maksimimin, aynı zamanda, genel bir yasa olmasını isteyebileceğim şekilden başka türlü davranmamalıyım”, "İstemenin, maksimleri aracılığıyla kendisini aynı zamanda genel yasa koyucu olarak görebilecek şekilde eylemde bulun!” vb. şeklindedir (Kant, 2009). 